\title{
Concept of the Name in the Tragedy "Romeo and Juliet" as an Element of the Cultural Code
}

\author{
Elena V. Kulikova ${ }^{1, *}$ Svetlana Valentinovna Gerasimova ${ }^{1, a}$
}

\author{
${ }^{1}$ Kosygin Russian state University (Technologies. Design. Art), Moscow, Russia \\ aEmail: metanoik@gmail.com \\ *Corresponding author. Email: Elena@Kulikova.pp.ru
}

\begin{abstract}
The article applies a new approach to the problem of the name concept in the tragedy "Romeo and Juliet". It is shown that W. Shakespeare's tragedy is considered in a context of medieval dispute of the realists and the nominalists discussing ratio of a name and essence. The authors proved that Juliette acts as a supporter of Renaissance interpretation of medieval nominalism, testifying to independence of the person from own name. Romeo and Juliet displace the memory of the deceased nameless first ancestor by their death, becoming the fundamental victim in the Foundation of the Renaissance world of love. Shakespeare shows how the process of replacing the cultural code of the middle ages, which asserts the importance of the name. These codes contradict each other.
\end{abstract}

Keywords: Shakespeare, nominalists, realists, name, mind, freedom, love

\section{INTRODUCTION}

The name issue became the key issue to Shakespeare's tragedy Romeo and Juliet. The translator should take into account the philosophy of the name now existing in the language of the original. In the context of Russian and English literature the philosophy of the name is based on the completely different traditions of perception. The concept of "name" in Russian and English culture is different, because the language personalities representatives of these cultures are different. Using the same concepts, the Russian speaking and English speaking people conceive different world view. If the Russian reader associates the mystery of the name with Imiaslavie (Russian: Имяславие, literally praising the name, "Name glory") , the works of Pavel Florensky, Sergiy Bulgakov, Alexey Losev, Metropolitan Veniamin Fedchenkov, Metropolitan Hilarion Alfeyev, and others, then the dispute between nominalists and realists about the essence of the name remained relevant in Shakespeare's time. The translator is intended not only to master the language of the original, but also to be familiar with the cultural code of the period of time, formed the author's concepts. Name in Shakespeare's works has reached the level of the most important element of the global cultural code. Everything hinges on it in the play. The philosophical drama started speaking love conflict language, which became an illustration for Shakespeare's spiritual search. There is no clearly identified philosophy of the name in the tragedy, the cultural code becoming second nature of people forces them to act, not to think, on top of all that the characters' actions have a pronounced semantics. A person in the Shakespearean world does not just expresses himself through actions, but the actions themselves become the language that the philosophical and cultural code of the epoch uses.

\section{CONFLICT IN THE TRAGEDY "ROMEO AND JULIET" AS THE REFLECTION OF THE DEBATES OVER THE NAME BETWEEN REALISTS AND NOMINALISTS}

The core conflict of the tragedy is based on the fact that the citizens of Verona are divided into two warring clans by the ancestral names of the Montagues or Capulets. The name and the debates over its importance and significance are at the center of the conflict. The Medieval Spirit is expressed, according to Shakespeare, by the name having life in its power.

The aesthetic views of the middle Ages and the Renaissance come into conflict in many plays by W. Shakespeare, and in the tragedy "Romeo and Juliet" the basis for contrasting medieval and Renaissance thinking is the philosophy of the name. The medieval tradition of not separating a name from a person for the playwright becomes one of the reasons for the collapse of medieval culture: the 
love of the family name degrades, degenerating into clan enmity and the absurdity of revenge for the spilled blood of a forgotten ancestor. However, the rooting of the name in the person has a sacred meaning for the middle ages, because the name connects a person with the saint patron, the echo of which he is thought. The adoption of a new name during monastic tonsure corresponds to the death of the old man for the world and the birth of a new one. The newly elected Pope adopts a name designed to symbolize what policies he will follow. Juliet's famous line: "What's in a name? That which we call a rose, By any other name would smell as sweet..." ("То, что зовем мы розой,// И под другим названьем сохраняло б // Свой сладкий запах!" Act 2, scene 2, translated by $\mathrm{T}$. Shchepkina-Kupernik Shchepkinoy-Kupernik "Роза пахнет розой, // Хоть розой назови ее, хоть нет" translated by Pasternak) [1].

This is not only an attack against medieval prejudices, but it has a very specific addressee-the medieval realists, who claimed the connection between the universal (Platonic idea, name) and substance (the essence of the object, being). Medieval realists (Anselm of Canterbury, Guillaume from Shampo, and Thomas Aquinas, who is close to them) claim that there is only the global, i.e., the Divine mind (sooth) and the universals that reside in it. All concrete objects and living beings are derivatives of universals. However, nominalists (Peter of Spain, W. Occam, J. Buridan) consider in the universal just a specified name that does not captures the essence of the of the called subject. Realism became the mainstay of Catholicism, while nominalism was renounced at the Council of Soissons in 1092.

Juliet is shown as a supporter of nominalists believed that the universal is just a name, a conditional idiom that is not able to be the essence of the named, that the name and being are not connected. The ideas expressed by W. Shakespeare by means of Juliet, in many ways go back to the ideas of William Occam -a nominalist philosopher that he submitted in "Epistemology": "Sic intentio animae dicitur universalis, quia est signum praedicabile de pluribus; $<\ldots>$ tale universale non est nisi intentio animae, $\langle\ldots\rangle$ Aliud est universale per voluntariam institutionem. Et sic vox prolata, quae est vere una qualitas, est universalis, quia scilicet est signum voluntarie institutum ad significandum plura" ${ }^{1}$ [2].

While realists believed that universals exist in the divine consciousness, Occam denies it, pointing

"The soul Intention is called universal because it is a meaningful sign $\langle\ldots\rangle$ such a universal is nothing else, but the intention of the soul, $\langle\ldots\rangle$ Another universal is set randomly And such universal is a spoken word, a truly unified quality, since it is a sign arbitrarily set for denoting a lot..." [2]. out that universal concepts are born in the human souls and objectively existing universals, realists believe in, do not exist.

The arbitrariness of the name turns the medieval memory family name and family honor into chaos through Juliette's eyes. W. Shakespeare brings the situation to the absurdity, because the name of the forefather and the cause of death have been forgotten, but it didn't erase the blood feud. In the role of the forefather in the tragedy there is a murdered ancestor, who became the reason of the feud between two clans in Verona.

The theme of the forefather is elaborated in religion and mythology. In the Bible his name is Adam, Purusha in the Ridvega and Yama in the Vedic tradition. It means that it is not separate phenomena but an archetype or universal of the forefather, who has different names in different cultures. Each tribe has its forefather, by this phenomenon can be defined an important theme for W. Shakespeare, theme of connection of his name with the clan descended from him, that is connection between the name and the essence. In W. Shakespeare's tragedy the archetype is travestied (almost turns into a parody), because he happens to be not the cause of life, but the cause of senseless death of people instead. So, based on the archetype of the forefather the connection of the name and the essence of a man leads not to the glory of life, but to the absurdity of the feud.

Juliette gets involved in the argument with personification and metaphor at the same time, trying to convince Romeo that he, just like the rose, would keep his identity and personal aroma even if he had a different name. People are only the shadows (random accidents) of ideas (universal) so death and blood are worthless. The shadows of people wander across the earth, and the idea of a bloodline (universal) stays forever. Idea is everything, man is nothing - this way the atmosphere of a medieval town can be expressed. W. Shakespeare exaggerates negatives consequences of the realism philosophy in order to put a specific existence above some general ideas.

The universal of the first ancestor in Verona detached from his name or accidentally established sign, but the universal is divine in the minds of the residents of the city and the connection with the name is sacred. The Veronese die for the patrimonial name like the first Christians were dying for the name of Christ. Not just die but also, unfortunately, kill. Thus, Shakespeare shows to what extent nominalism has degraded in the minds of people and what hell on the earth it leads to. Shakespeare argues with nominalists carrying their judgements to the point of absurdity: if the name as the most important element of the culture code of the era reflects the essence of things and 
phenomena then people will kill each other thinking that they are fighting for the essence, but in fact they will die for the sound, for the emptiness and for the right to be called by one name or another Montague or Capulet.

\section{THE DISPUTE OF MIND AND HEART IN THE TRAGEDY AS THE CONSEQUENCE OF THE DISAGREEMENT BETWEEN REALISTS AND NOMINALISTS}

Romeo and Juliet is a tragedy with heroic pathos. The main characters do not know the inner conflict although it is potentially planned. The medieval mind teaches to appreciate the name. The Renaissance invokes to steel willpower in the aspiration to love and not to be tempted by the persuasion of the mind that it is necessary to honor your patrimonial name and to obey warring parents.

Memory is the most important manifestation of the mind, but the motive of memory in the tragedy is intertwined with the motive of rancor that is opposed by love and happiness. In Shakespeare's book the antithesis of mind which generates revengeful ideas and passion, and the antithesis of will which invokes to love are also projections on the plot of the dispute between realists and nominalists about the secret of the Creator, about creator's divine origin because the Divine mind as the container of ideas (from the point of realists' view) was opposed with the Divine will by nominalists.

The realists and nominalists dispute is the eternal dispute of idealists and materialists. From the point of realists' view, the truth included its universals, precedes various particular forms of being: "An pulas aliquid esse aliquando, aut alicubi, quod non sit in summa veritate, el quod inde non acceperit quod est, inquantum est: aut quod possit aliud esse, quam quod ibi est". ${ }^{2}$ [3]

The answer will be negative. Nominalists believe that the concrete forms of being precede the universals and determine such a capacity of consciousness like giving names to everything: "Sicut est de hoc nomine "homo"; "homo" enim primo imponebatur ad significandum omnia animalia rationalia, ita quod imponebatur ad significandum omne illud, quod continetur sub hoc conceptu "animal rationale" ${ }^{3}[2] ;-$ W. Ockham

\footnotetext{
"Teacher. Do you think that there is something some time or somewhere that does not exist in the supreme truth and that has not received from it something that it is now since there is; or that something could be different from that that is in it?" [3].

"Indeed, previously the name 'human' was used for the denomination of all reasonable living beings, so it was used to denominate every thing that came under the category 'reasonable living being'" [2].
}

ponders in "Logic". But some other thing is more important: for realists, the origin of being is in heaven, in the Divine mind that creates ideas. And for nominalists it is in the Divine will, therefore, the mind of a human is not connected with the mind of the Creator, it contemplates everything earthly and it is earthly itself. The perceptions of a human are the reflection of the perceptions of the Creator. The Renaissance interpretation of nominalism not only recognizes the supremacy of matter over name but also comprehends a human in the context of the creative ability to willfully create one's own destiny.

The Renaissance dream of a forceful personality, who can create destiny, is perchance only in the context of nominalism. Realism proceeds from the exact reverse point of view. In fact, a universal stands over each person-Creator's plan for him. People need an ecclesiastical afflatus to understand this idea. Living on your own is a terrible spiritual poverty. Happiness is to fulfill God's will for yourself.

For the Renaissance, bliss is to live of your own accord and create your own destiny.

In the context of the tragedy "Romeo and Juliet", on the one side, the characters with medieval mind is contraposed, whose intellect is addled by common notion of honor, the universal of the forefather. For W. Shakespeare, existence is superior than consciousness, even the daring, Renaissance mind of brother Lorenzo, who made a motion of scenario with Juliet's apparent death and her future returning from the dead, mind, that realizes its dominion over people's destiny and desire global bliss - even his intelligence is existence determines consciousness almighty entity since human reason cannot foresee all the possibilities. The play repeatedly debunks the mind, which is not typical for such works by W. Shakespeare of the first period (1590-1600), as "The Merchant of Venice" (1596), in which happy end turns out feasible by virtue of Porcia's intellect, or "Much Ado About Nothing" (1600), where the wit of the characters verge towards happiness. W. Shakespeare evolves the Boccaccio's tradition because in The Decameron characters often blissful due to their inventiveness and wittiness as in novel about rings (1 day, 3 novel) [4]. The Renaissance person is sharp-witted. But in the conceptual tragedy of Romeo and Juliet (1594-1595) the consciousness powerless in the face of force of being, and brother Lorenzo cannot envisage the pestilence, in consequence of which Romeo will not know that Juliet is alive because the wits is the world, which germinates Celestial universals and abstract terms, while as W. Shakespeare aspires to seal the exultation quotient over common and volition over reason is the exultation of nominalism over realism because intellect in his tragedy is 
feeble and doomed to failure (as in the case of brother Lorenzo), or even doomed to death (as in the case of Mercuzio), but the affectionate heart and free agency of person can comprehend the Verity.

In the dispute started by nominalists and realists, the key concept was "the name of the rose", which goes back, according to A. G. Orlova [5] , to "Logic for the beginners" by Pierre Abelard. U. Eco in the "Postscript to The name of the rose", name of the rose" " indicates "De contemptumundi" by Bernard of Morlan (XII century) [6].

The choice of Juliet in favor of nominalists is symbolic because the Renaissance personality considers itself in the categories of nominalism and for the Renaissance of the person associates with freedom and will. It is not just a subject to general rules. W. Shakespeare considers the principles of the realists as the incarnation of the dark Middle Ages. For the Renaissance understanding, the idea of memory, which is the beautiful in the context of medieval culture, turns into an ugly rancor, and obedience to General rules (universals of social relations) from a sign of mutual respect and even love becomes a symbol of violence against a unique and the only and person. The world of reason, memory and general concepts is presented in the tragedy as a medieval hell, which is opposed by the Renaissance aesthetic of unique joy and will to be specific people.

On the plot level this step from medieval realism to Renaissance interpretation of nominalism is presented as a denial of the absurd medieval cult of ancestor memory (i.e., the denial of the mind and General ideas-universals) and as an approving of new ideals. First, the ideal of free will, which means that manifests itself, primarily in the act of creating one's own destiny. W. Occam, who asserted the divine will of the Creator and the primacy of the will over the mind is regarded as the medieval forerunner of the reformation. The person of Renaissance builds his own destiny acting like the Creator of the nominalists. The Creator who creates the world by the greatness by his will but not by the reason. Secondly, it is an attempt to approve the ideal of a private, original life, the ideal of a person who avoids authoritarian of the system (and universals).

Not just common sense and reason triumphs in the denouement of the tragedy at the moment of reconciliation of the Montague and Capulet clans it, but mostly a person's desire for love, for the creativity of their own destiny. Love in tragedy is a force that creates a new Renaissance cosmos. The name is the most important code of the medieval culture. Renaissance considered that only overcoming the prejudices associated with the name will enable creating a Renaissance Paradise. The name will be the most important symbol of the
Renaissance cultural code, but it must be rejected for the triumph of the loving heart not the reason.

\section{ORIGINS OF THE ANTITHESIS OF LOVE AND NAME (WORDS) IN TRAGEDY}

The opposition of love and name (universal) can be often found in tragedy. The translation made by T. Schepkina-Kupernik reproduces the Shakespearean text as accurately as possible: in the 6th scene of Act II, Romeo, paying tribute to Juliet's mind and taste, invited her to describe in words the ineffable bliss of love, but he heard in response:

\section{Conceit, more rich in matter than in words,}

Brags of his substance, not of ornament.

\section{But my true love is grown to such excess}

I cannot sum up sum of half my wealth.

Shakespeare is a nominalist, and the word is powerless to express the substance. Love is the highest substance. The word is powerless against love. If "Summa theologiae" by Thomas Aquinas claims to reveal the secret of the Creator in the word, then love needs the "Sum" of its own. Shakespeare's theology of love is wordless when it meets its mystery. Shakespeare subverts realism with its trusting in word. If it is powerless against the secret of Love, then the "Sum of theology" (Recalling hamlet's aphorism) is only words, words, words... The substance of love in Shakespeare's view must conquer the world of words and names that generate war. Romeo is more stung by medieval realism and seeks a correspondence between entities and universal names, for example, at the moment when he wants to find and pierce with a sword the place in his body in the place where his name is concentrated in his body, so that it does not separate him from Juliet. This infestation of the middle Ages makes Romeo more vulnerable and, perhaps, that was the reason for his death, for he did not wait for the resurrection of the Renaissance Sleeping beauty - Juliet. In W. Shakespeare's comedies the Renaissance is a world in which fairy-tale hopes come true, but tragedies need to have nothing alien to the Renaissance in the characters for a miracle. In comedies, such as " Much Ado About Nothing" Hero has resurrected for Claudio, in "Twelfth night" miraculously surviving sister Viola has resurrected for Sebastian, a similar situation is in the tragicomedy "The Tempest". The fabulous- comedic plot is based on overcoming the fear of death. But Romeo absorbed fear for death with his mother's milk - a medieval reverence for the word and the name. The wit Mercutio is also infected with the word's saponaceousness. The medieval idea (the universal) 
of the first ancestor hardens the soul of Tybalt. All these heroes are doomed to die

W. Shakespeare uses his character Mercutio for chastising wittiness as an attribute of nominalistic mind. For nominalists, the intelligibility of world relates with the fact that the world is based on universals the Divine ideas, by perceiving which, human mind cognizes the world, which, from the point of view of realists, is being perceived not because of experience, but because of similarity between nature of Creator's and human mind.

The ideas of everything being are captivated in the very sense of the Creator, when human mind exists in the accordance with his intelligent nature, which is similar to the nature of Divine mind, the essence of all the things opens to such person - the mind beholds the universals and Divine ideas of everything that exists. The human mind meets the Divine one and cognizes the earthy world due to it. Mercutio's mind constantly poises in the area of universals: not only the Queen Meb's secret becomes revealed to him, but comparing Tybalt with Tybert, the cat from the medieval "Novel of the Fox," he gives a capacious and accurate characterization for the first one. Without relying on his experience, Mercutio comprehends the world of ideas by his imagination, becoming a living embodiment of the principle of world outlook of philosophers-realists. Mercutio's death is often explained by coldness of his brilliant mind However, witty Shakespearean characters are often cold and realistic, for instance, Isabelle from his comedy 'Measure for Measure'. Witness prevented none of his characters from being happy. None except for Mercutio, who was the victim of a dispute between the playwright and the nominalists, who unlike W. Shakespeare exalted the rational origin of the universe, but not creative mind.

Juliet is shown by starting her development from an addiction to the name - to gaining free creative will. At the beginning of the tragedy, she confesses to Romeo that she would like to keep him at a short distance:

\section{'Tis almost morning; I would have thee gone:}

\section{And yet no further than a wanton's bird;}

Who lets it hop a little from her hand $<\ldots>$ So loving-jealous of his liberty.[1] This short distance ("short leash" in Russian translation by ShchepkinaKupernik) for Juliet was the name and the voice, because, before saying her famous lines about the bird, constantly calls Romeo by his name, confessing she could caress him to death. In the middle of the action, Juliet is forced to cut off this short thread of the name and let Romeo go into exile, where her voice cannot reach: " $\mathrm{O}$, now be gone; more light and light it grows." (Scene 5 of Act III) [1], she is ready for the unpredictable creativity of her fate. Instead of a word and a name, which had power over life and were the most important element of Medieval cultural code, Renaissance proclaims love and freedom, which turn into parts of its cultural code, coming to replace the name.

\section{VIEWING FROM THE PRINCIPLE OF INTERCHANGEABILITY IN TRAGEDY TO ABSURDITY}

The concept of the victim of the first ancestor becomes the key idea of medieval hell in the tragedy. The mission of Romeo and Juliet, according to W. Shakespeare, is aimed in supplanting and replacing this idea. If the world of the Middle Ages is based on the idea of revenge for the ancestor, whose name has been forgotten, then the world of the Renaissance will be based on love for him. Romeo and Juliet will become an analogue of the first ancestor. The first ancestor in stories of different periods and origins and often perishes for the sake of well-being and the improvement of the world, becoming a fundamental victim that formed the basis of a new world of love. So, the protagonists take on the role of the ancestor and fundamental victim

If the name is random, then the forgotten name of the ancestor, on which the world of enmity is based, will be replaced with the name of the lovers Romeo and Juliet.

Shakespeare's names can be interchangeable, but they are never meaningless. The names of the lovers who eclipsed his death with their own, will be in the basis of the world of love.

For W. Shakespeare, the absurdity of the medieval world became a derivative of the philosophy of realists (the absurdity of war over a name). In the Middle Ages, the aesthetics of the absurd was more often associated with the philosophy of nominalists, with their idea of the convention of a name.

Juliet also passes the temptation of the medieval metaphorical absurdity, recalling the figurative structure of ballad by F. Villon:

Dove-feather'd raven! wolvish-ravening lamb!

Despised substance of divinest show!

(Scene 2 of Act III of the tragedy "Romeo and Juliet").

Her lines can be compared with Villon's "Ballad of the Poetic Competition at Blois": "Mon ami est, qui me fait entendant // D'un cygne blanc que c'est un corbeau noir". ("My friend is the one who agrees with me that the white swan is a black raven"). 
However, the heroine quickly overcomes this temptation with the medieval understanding of nominalism, with its tendence to juggle metaphors and names in the hope that it will be possible to express the ineffable in a mysterious form. Juliet quickly returns to the Renaissance interpretation of nominalism (i.e. the doctrine of an arbitrarily of a given name) and asserts the superiority of the human will to love over an imperfect mind limited by random events.

There is an interesting trace of the dispute between W. Shakespeare and medieval realists in the scene where Romeo cries in his brother Lorenzo's cell after the murder of Tybalt. Romeo feels sorry not just because of the murder but because of the fact that he has his name, trying to kill him in himself, and therefore proving the inseparability of the name from the essence,

" $O$, tell me, friar, tell me,

In what vile part of this anatomy

Doth my name lodge? tell me, that I may sack The hateful mansion."

(Scene 3 of the III act of the tragedy "Romeo and Juliet") [1].

After that brother Lorenzo accuses Romeo for being a man but crying like a woman. And the reader (viewer) again finds himself in the nature of medieval nominalism, where crows are doves or swans, and men are essentially women. But all these are forms of the medieval absurdity culture, which is close to laughter and is generated by the profane existence of the philosophy of nominalism. Perhaps the literary figure of a philosopher nominalist is profaned in folklore as a type of a jollier-jokester, a funny man and even a jester.

So, the Middle Ages find its potential of absurdity among the philosophical categories of nominalism, and the Renaissance among the categories of medieval realism, which proves an important cultural breakdown, reflected in the work of W. Shakespeare, who in the tragedy "Romeo and Juliet" opposes the dark, lost mind of medieval realists the Renaissance will to being, based on the interpretation of the Divine will of the nominalist philosophers, in particular - W. Ockham, who believed that the source of being is precisely the will, not the mind. The convention of the name (swan - Villon's raven and swan - Juliet's dove) destroys the idea of the wholeness and rationality of the world, which becomes irrational, as if something is unsaid in it and an insight is required, because of which the absurd world gains lost semantic clarity. The absurd figurativeness, dating back to the philosophy of nominalists, is asserted in culture as a way to indicate the semantic incompleteness of the word which will be researched in other kinds of art. Later, "incompleteness and apparent fragmentation" [7] of thoughts will be inherent in Blaise Pascal. And illustrations, in contrast to the text, will be created in order to have "comprehensive historical information" [8], i.e., semantic completeness. Some researchers believe that even music is a "semiotic system" [9]: it seeks to generate semantically complete phrases. The word, however, aims to overcome its nature and become internally contradictory and requiring insight for its comprehending. Although "there is no catharsis in absurdist plays" [10], insight is the catharsis of medieval absurdity.

\section{CONCLUSION}

Shakespeare shows how the process of replacing the cultural code of the middle ages, that asserts the importance of the name and mind, by the cultural code of the Renaissance, that exalts freedom and love. These codes contradict each other.

\section{References}

[1] William Shakespeare. Romeo and Juliet / translation by T. Shchepkina-Kupernik // Complete works in one volume, Moscow: alpha-kniga, 2008, Pp. 289, 294, 298. William Shakespeare Romeo and Juliet / / URL: http://shakespeare.mit.edu/romeo_juliet/full.html. Date of access: 05.09.2020

[2] William of Ockham. Selected works / translated from Latin by. A.V. Appolonova and M. A. Garntseva , General edition by A.V. Appolonova. M.: Editorial URSS, 2002. 272 p. P. $116-118$; P. 24

[3] Anselm Of Canterbury. About the truth / / anthology of medieval thought: Theology and philosophy of the European middle ages: in 2 vols. Edition by S. Neretina. SPb.: RKHGI; amphora, 2008. P. 203-230. P. 215

[4] Giovanni Boccaccio. The Decameron / / Translated by Mark Musa and Peter Bondanella/ / Published by Signet Classics, New York, 2002 752s. P. 64

[5] A. G. Orlova Logical and philosophical problems in the novel by U. Eco "Name of the rose" / / SPb., 2008-2009. URL: http://turbaphilosophorum.narod.ru/forskninger/Orlova/2_Eco_Rose.h tml accessed 05.09.2020

[6] Umberto Eco. Postscript to The name of the rose / San Diego: Harcourt Brace Jovanovich, 1984. 84 p. 5.

[7] K. Yu. Kashlyavik. Textual problems of publishing Pascal's "The thoughts"// News of higher educational institutions. Problems of printing and publishing. 2009. No 3. P. 97-105. P. 97

[8] T. A. Karmanenko Dependence of information content of illustrations of handwritten lives of the XVI century on images of the architecture of monasteries// News of higher educational institutions. Problems of printing and publishing. 2011. No. 6. P. 100-104. P. 101

[9] A. Yu Filippovich., I. V. Golubeva Investigation of the syntax of semiographic chants// News of higher educational institutions. Problems of printing and publishing. 2012. No. 6. P. 147-163. P. 149.

[10] V. A. Pronin. Art and literature abroad. Moscow: 2003. P. 226. 